\title{
THE HAYEK PENSION AN EFFICIENT MINIMUM PENSION TO COMPLEMENT THE WELFARE STATE
}

JAKOB VON WEIZSÄCKER

CESIFO WORKING PAPER NO. 1064

CATEgory 1: Public Finance

OCTOBER 2003

An electronic version of the paper may be downloaded

- from the SSRN website: www.SSRN.com

- from the CESifo website: www.CESifo.de 


\title{
THE HAYEK PENSION AN EFFICIENT MINIMUM PENSION TO COMPLEMENT THE WELFARE STATE
}

\begin{abstract}
A means tested minimum income for old age creates an incentive for some not to save for old age and instead to free ride. Recent literature is undecided to what extent this inefficient savings distortion should be addressed by a compulsory pension system because resulting labour-leisure distortions could be even worse. In a simple optimal taxation framework we show that it is Pareto improving to fully eliminate the savings distortion by means of a compulsory pension termed "Hayek pension" that decreases with after-tax lifetime earnings, with zero pension benefits for middle and high incomes. A combination of the Hayek pension and the contribution dependent Bismarck pension is found to be superior to the tax financed flat benefit Beverage pension.
\end{abstract}

JEL Classification: H55, I38.

\author{
Jakob von Weizsäcker \\ The World Bank \\ 1818 H Street, $N W$ \\ Washington, DC 20433 \\ USA \\ jvonweizsacker@worldbank.org
}

I would like to thank Peter Diamond, Robert Fenge, and Stefan Homburg for their helpful comments and the Center for Economic Studies in Munich for its hospitality. Of course, the mistakes expressed herein are my own and the views expressed herein do not necessarily reflect the views of my employer. 


\section{Introduction}

Do we need compulsory pensions for efficiency if we take means tested minimum income in old age as given? Friedrich von Hayek (1960), who should be above any suspicion of having an unfair bias in favour of compulsory schemes, thought so:

"Once it becomes the recognized duty of the public to provide for the extreme needs of old age, unemployment, sickness, etc., irrespective of whether the individuals could and ought to have made provisions themselves, and particularly once help is assured to such an extent that it is apt to reduce individuals' efforts, it seems an obvious corollary to compel them to insure (or otherwise provide) against those common hazards of life."

Concepts closely related to this savings moral hazard were elaborated by several other authors. For example, Lindbeck and Weibull (1988) formalize the savings moral hazard argument for two altruistic agents in a two stage game. Hubbard, Skinner, and Zeldes (1995) explain the low level of savings in a large part of the US population on the basis of the savings moral hazard induced by means tested social insurance. Mulligan and Sala-i-Martin (1999) in their classification of justifications of state pension systems term the savings moral hazard the "rational prodigality" argument ${ }^{2}$.

Hayek's obvious corollary was confirmed explicitly for old age pensions by Fenge and Weizsäcker (2001) in a formal model with two productivity types, the rich and the poor. They assume linear taxes and pension contribution rates. In essence, the means tested income for old age gives an incentive to save too little, driving a wedge between the marginal utility of consumption in youth and old age. This inefficiency can be addressed with compulsory savings. The introduction of compulsory savings is Pareto-improving to the extent needed to prevent the rich type from free riding on the means tested income in old age. The reliance of the poor on the means tested minimum income also implies a consumption distortion, but at the same time it implies a redistribution to the poor since the means tested minimum income is tax financed and therefore at least partially financed by the rich type. Whether the poor type should also be prevented from free riding on the means tested minimum income therefore depends on the redistributional objectives implicit in the chosen social welfare function.

\footnotetext{
2 As opposed to the "myopic prodigality" used in Feldstein (1985) where agents simply lack foresight. This possibility is already emphasised by Diamond (1977) and is now often modelled by hyperbolic preferences (Laibson, 1997).
} 
By contrast, Homburg (2000) considers the same problem in a model with labour-leisure choice and a continuum of productivity types, yet also relying on the assumption of linear taxes and pension contributions. Interestingly, in his model Hayek's obvious corollary does not generally hold since the introduction of compulsory savings reduces the number of nonsaving workers in both a desirable and an undesirable way. Desirably, some of them join the group of saving workers. Undesirably, some previously non-saving workers perceive the compulsory saving requirement as an additional labour tax and stop working altogether, relying on the state not only in old age but also in their prime. This latter labour-leisure distortion introduced by the pension system may in fact be worse than the savings distortion it is meant to cure. Using this effect, Homburg constructs a numerical example where it is optimal to have no compulsory pension system at all and to fully accept the presence of "nonsavings workers".

We re-examine the issue of compulsory savings by allowing for optimal taxation and pension contribution schedules that do not necessarily have to be linear. In additional to the theoretical appeal, this is motivated by the fact that income tax schedules are far from linear in practice. Small incomes tend to be tax exempt and most countries do have a progressive income tax schedule. Furthermore, piecewise changes to the tax schedule are frequent and easily implemented. The presence of a means tested minimum income for old age is still taken as given, since it has indeed "become the recognized duty of the public to provide for the extreme needs of old age" in many countries.

In our more general framework Hayek's corollary is restored. Specifically, it is shown that the presence of "non-savings workers" will never be optimal since it would always be possible to offer them a simple welfare enhancing pension reform package that increases their compulsory savings and lowers their income taxes, thus inducing them to provide for their old age themselves. This type of reform is Pareto improving. Targeted reform steps as outlined here will be Pareto improving even far away from the optimal tax and contribution schedule, hopefully increasing the policy relevance of the results presented here.

In practical terms, we derive an efficient minimum pension system where pension benefits decrease with after tax lifetime earnings, with zero benefits for middle and high income groups. This is in contrast to most existing state pension systems. According to the definitions of Cremer and Pestieau (1998) it is notably neither a Beveridge pension with flat benefits nor 
a Bismarck pension with contribution related benefits. Also, the pension system we derive is not a means tested pension, as discussed for example by Friedman and Cohen (1972) and Feldstein (1987), since the proposed benefits depend on past lifetime income rather than current income or assets. To emphasize this contrast we call the efficient minimum pension system "Hayek pension". The advantages of a Hayek pension compared to a Bismarck or Beveridge pension are discussed. A combination of the Hayek pension and the contribution dependent Bismarck pension is found to be superior to the tax financed flat benefit Beverage pension. 


\section{The Model}

Consider a model where economic agents live for two periods and maximize their utility function

$$
U\left(c_{1}, c_{2}, 1-l\right)=u\left(c_{1}\right)+u\left(c_{2}\right)+v(1-l)
$$

First and second period consumption are $c_{1}$ and $c_{2}$ respectively and $u$ and $v$ have the usual properties. Labour $l$ is only supplied during the first period and first period leisure is normalised to one. For simplicity, both the rate of discount and the interest rate are assumed to be zero.

Each agent faces the following individual maximisation problem:

$$
\begin{array}{ll}
\max _{c_{1}, c_{2}, s \geq 0, l} & U\left(c_{1}, c_{2}, 1-l\right) \\
\text { s.t. } & c_{1}+s=\max \{w l-T(w l)-B(w l) ; a\} \\
& c_{2}=\max \{s+B(w l) ; a\}
\end{array}
$$

Gross income of each agent is given by $w l$ where $w$ stands for the labour productivity of each agent. Both total tax payments $T(w l)$ and total compulsory pension contributions $B(w l)$ are a function of gross income. The pension system is assumed to be actuarially fair with a perfect tax-benefit link so that the net present value of the sum of pensions contributions during youth and pension payments in old age is zero. In addition to the compulsory pension system, agents can provide for old age with their savings $s$. There is a means-tested minimum income at level $a$. If wealth plus earnings in any of the two periods is below the socially accepted minimum $a$, the government provides for the remainder so that everybody is guaranteed the minimum income $a$ both during youth and in old age.

Given the minimum income and a distribution of skills $f(w)$ the government aims to maximize a given social welfare function as in Mirrlees (1971), setting an appropriate tax level $T($.$) and a pension contribution level B($.$) as a function of income - not of productivity$ since productivity is unobservable for the government. 
The key assumption in this set-up is the separability of labour in the utility function ${ }^{3}$. The other simplifying assumptions have been adopted to improve the clarity of exposition without loss of generality. A generalization that allows for, among others, a more general utility function and different minimum income levels during youth and old age, is given in the appendix.

Proposition: The presence of non-savings workers is never efficient since a welfare improving reform mix will always exist, targeting the non-saving workers with increases in mandatory pension contributions and tax reductions.

Proof: The maximisation problem of any non-saving worker amounts to

$$
\max _{c_{1}, c_{2}, s \geq 0, l} U\left(c_{1}, c_{2}, 1-l\right) \quad=u(I-B(I)-T(I))+u(a)+v\left(1-l^{*}\right)
$$

$$
\begin{array}{rlrl}
\text { s.t. } & & c_{1}=w l-B(w l)-T(w l) \\
& c_{2}=a
\end{array}
$$

where $I=w l^{*}$ is the labour income and $l^{*}(w)$ is the optimised labour supply. In particular, for the non-saving worker the consumption utility when relying on the minimum income is greater than the consumption utility when not relying on the minimum income:

$$
u(I-B(I)-T(I))+u(a)>2 u\left(\frac{I-T(I)}{2}\right)
$$

Figure 1 illustrates the consumption point $\mathrm{C}$ for the non-saving worker with first period consumption $I-B(I)-T(I)$ and consumption $a$ in the second period.

\footnotetext{
${ }^{3}$ Homburg (2000) also uses separability of labour in the utility function. Hence, the results derived here also apply to his model.
} 


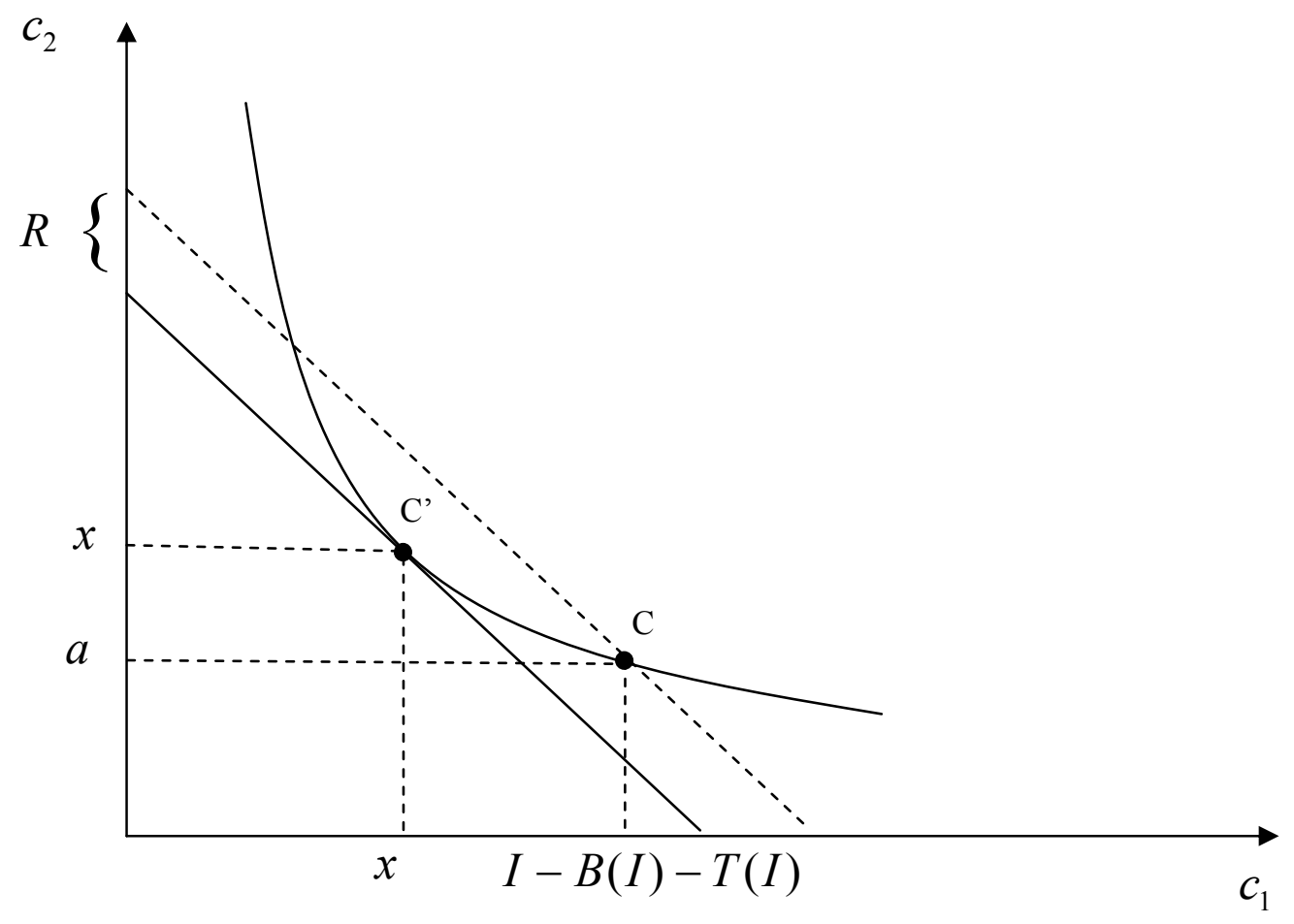

Figure 1: A resource saving shift from consumption point $C$ to $C^{\prime}$

The strategy of the proof is to show that a reform of the tax and contribution system $T, B \rightarrow \widetilde{T}, \widetilde{B}$ exists that:

i) shifts the consumption point of any non-saving worker from consumption point $\mathrm{C}$ to the consumption point $\mathrm{C}^{\prime}$, the point on the indifference curve going through $\mathrm{C}$ that requires the minimum lifetime consumption. This shift is accomplished without changing the labour supply.

ii) does not induce any other agents to change their labour supply and lifetime consumption pattern.

In a first step, such a reform would leave everybody indifferent. However, the resource savings $R$ indicated in Figure 1 that result from the consumption shift $C \rightarrow C^{\prime}$ accrue with the state as a windfall ${ }^{4}$. This windfall could in a second reform step be used to improve welfare by an appropriate mixture of tax reductions and increased public spending. The second reform step does not need to be specified since the marginal utility of such windfall public funds will always be positive. 
We consider the following reform $T, B \rightarrow \widetilde{T}, \widetilde{B}$

$$
\widetilde{T}(I)=I-2 x, \widetilde{B}(I)=2 x-I+T(I)+B(I) .
$$

for all gross incomes $I$ for which workers are non-saving, with

$$
x=u^{-1}\left(\frac{u(I-T(I)-B(I))+u(a)}{2}\right)<\frac{I-T(I)-B(I)+a}{2}
$$

This inequality holds because of the assumed convexity of preferences.

We can also verify that this reform does in fact increase compulsory savings and reduce taxes by the same amount

$$
\begin{aligned}
& \Delta B=\widetilde{B}(I)-B(I)=2 x-I+T(I)>0 \\
& \Delta B+\Delta T=(2 x-I+T(I))+(I-2 x-T(I))=0
\end{aligned}
$$

Starting with (4), we have $u(I-B(I)-T(I))+u(a)>2 u([I-T(I)] / 2)$. Applying the inverse function of $u$ to both sides and using definition (6) this implies $x>[I-T(I)] / 2$. Hence indeed $\Delta B=2 x-I+T(I)>0$.

For all gross incomes $I^{\prime}$ with no non-saving workers, the income tax and pension contribution schedule is left untouched

$$
\widetilde{T}\left(I^{\prime}\right)=T\left(I^{\prime}\right), \widetilde{B}\left(I^{\prime}\right)=B\left(I^{\prime}\right)
$$

Assuming for the time being that the reform does not change the labour supply of the nonsavings workers, one can show that for incomes $I$ where previously non-saving workers existed, agents are now indifferent between claiming the minimum income in old age and providing for their old age themselves.

Post reform, the utility of an agent when claiming the minimum income in old age is given by

\footnotetext{
${ }^{4}$ Technically, these non-zero resource savings accrue if the shift takes place for a set of agents that has non-zero mass in the productivity distribution $f(w)$.
} 


$$
\max _{c_{1}, c_{2}, s \geq 0, l} U\left(c_{1}, c_{2}, 1-l\right) \quad=u(I-T(I)-B(I))+u(a)+v\left(1-l^{*}\right)
$$

$$
\begin{aligned}
\text { s.t. } & c_{1}=w l-\widetilde{T}(w l)-\widetilde{B}(w l)=w l-T(w l)-B(w l) \\
& c_{2}=a
\end{aligned}
$$

and the utility when not claiming the minimum income is given by

$$
\begin{array}{ll}
\max _{c_{1}, c_{2}, s \geq 0, l=l^{*}} U\left(c_{1}, c_{2}, 1-l\right) & =u(x)+u(x)+v\left(1-l^{*}\right) \\
\text { s.t. } & c_{1}+s=w l-\widetilde{T}(w l)-\widetilde{B}(w l)=w l-T(w l)-B(w l) \\
& c_{2}=\widetilde{B}(w l)+s
\end{array}
$$

Using (6) we obtain

$$
u(I-T(I)-B(I))+u(a)+v\left(1-l^{*}\right)=u(x)+u(x)+v\left(1-l^{*}\right)
$$

Indeed, any agent with a gross income fixed at $I$ is now indifferent between claiming and not claiming the minimum income.

In addition, from equation (11) it follows immediately that potential mimickers - if they were to choose to earn income I with a different productivity $w^{\prime}$ - would also be indifferent between claiming and not claiming the minimum income.

$$
u(I-T(I))+u(a)+v\left(1-l^{*} w / w^{\prime}\right)=u(x)+u(x)+v\left(1-l^{*} w / w^{\prime}\right)
$$

Since the pre-reform utility level that a potential mimicker could reach is the same as the postreform utility level, changing one's labour supply to mimick a different productivity type is no more attractive after the reform than it was before the reform for any individual. It is worth noting that (12) holds because of the key assumption that leisure and consumption are separable in the utility function.

With (12) it is clear that labour supply for all productivity types will indeed stay the same as before the reform. In particular, (12) justifies our working assumption that the same $l^{*}$ could be assumed in equations (10) and (11). Hence, everybody is indeed indifferent about the proposed reform. 
By convention, in case of indifference the minimum income is not claimed. As a result, the reform does have a budgetary effect. Net government expenditure for a worker is calculated as the difference between lifetime consumption and lifetime earnings. For a non-saving worker with productivity $w$ and income $w l^{*}$ claiming the minimum income before the reform, net government expenditure was $a-T\left(w l^{*}\right)-B\left(w l^{*}\right)$. After the reform, net government expenditure for the same productivity type amounts to $-\widetilde{T}\left(w l^{*}\right)=2 x-w l^{*}$ according to (15). By assumption, non-saving workers were present before the reform. More formally, non-savings workers had a non-zero mass before the reform

$$
\int_{0}^{\infty} g(w) f(w) d w>0
$$

where $g(w)$ is a binary function that is 1 if productivity type $w$ was a non-saving worker before the reform and 0 otherwise. Using inequalities (6) and (13) it is clear that the budget windfall due to the reform is indeed positive:

$$
\int_{0}^{\infty}\left(a-T\left(w l^{*}\right)-B\left(w l^{*}\right)-2 x+w l^{*}\right) g(w) f(w) d w>0
$$

Since the marginal utility of additional public funds is always positive, the proposed reform is welfare improving. This completes the proof.

The reform approach used in the proof does not rely on any particular welfare function. In fact, as is clear from the exposition, a Pareto-improving reform that forces previously nonsaving workers to save can always be found. 


\section{Derivation of the Hayek pension}

We now examine the overall shape of this Pareto-improving pension reform, starting from a situation without any compulsory savings $B(.) \equiv 0$. The Pareto-improving reform is not uniquely determined since increases in compulsory savings could be offset by decreases in private savings. To capture the range of Pareto-improving pension systems that eliminate the inefficiency of non-saving workers, we look at both the smallest pension system $B^{\text {min }}$ and the largest ${ }^{5}$ pension system $B^{\max }$ whose introduction would have the desired effect.

We first try to characterize $B^{\min }(N)$ which we will also refer to as the "Hayek Pension". Positive compulsory savings are only called for when

$$
u(N)+u(a)>2 u(N / 2)
$$

where $N=I-T(I)$ is the pre-reform after tax labour income (by assumption $B(.) \equiv 0$ to start with). When compulsory savings are called for to achieve efficiency, the smallest efficient compulsory savings level as a function of $N$ can be obtained, starting from a situation with no compulsory savings, by using (5) and (6)

$$
B^{\min }(N)=2 u^{-1}\left(\frac{u(N)+u(a)}{2}\right)-N
$$

It can now be shown that $B^{\text {min }}$ decreases with $N$

$$
\begin{aligned}
& \frac{d B^{\min }(N)}{d N}=\frac{u^{\prime}(N)}{u^{\prime}\left(u^{-1}\left(\frac{u(N)+u(a)}{2}\right)\right.}-1<0 \\
& \Leftrightarrow u^{\prime}(N)<u^{\prime}\left(u^{-1}\left(\frac{u(N)+u(a)}{2}\right)\right) \\
& \Leftrightarrow N>u^{-1}\left(\frac{u(N)+u(a)}{2}\right) \\
& \Leftrightarrow u(N)>u(N) / 2+u(a) / 2 \\
& \Leftrightarrow N>a
\end{aligned}
$$

\footnotetext{
${ }^{5}$ As in (2) we assume for this that future pension entitlements cannot be used as collateral and hence that private savings cannot be negative. Therefore, pension benefits are inefficiently generous when they are larger than the unconstrained second period optimum.
} 
But $N>a$ is a necessary condition for an agent to work at all. If it is violated, the agent would always prefer not to work and to consume $a$ in both periods. So it is indeed the case that in the optimum, lower net incomes are made to pay higher compulsory savings. In particular, we note that $B^{\min }(\bar{N})=0$ where $\bar{N}$ is the after tax income for which the agent is indifferent between saving and not saving even in the absence of compulsory savings, defined by $u(\bar{N})+u(a)=2 u(\bar{N} / 2)$. We also note that $B^{\min }(a)=a$. The typical shape of $B^{\text {min }}$ is given in Figure 2 by the bold solid line.

We now turn to the shape of $B^{\max }$ as a function of pre-reform net income $N$. For net incomes above $\bar{N}$ the unconstrained optimum second period consumption and hence the maximum efficient compulsory savings level is $B^{\max }(N)=N / 2$. For net incomes between $a$ and $\bar{N}$ the maximum efficient pension benefit level as a function of $\mathrm{N}$ follows from (6) and is given by $B^{\max }(N)=u^{-1}((u(N)+u(a)) / 2)$. In particular, we note that $B^{\max }(a)=a$ and $B^{\max }(\bar{N})=\bar{N} / 2$. For $N$ between $a$ and $\bar{N}$ it can also be shown that $0<d B^{\max } / d N<1 / 2$ and that $B^{\max }(N)>N / 2$. The typical shape of $B^{\max }$ is given in Figure 2 by the bold dashed line.

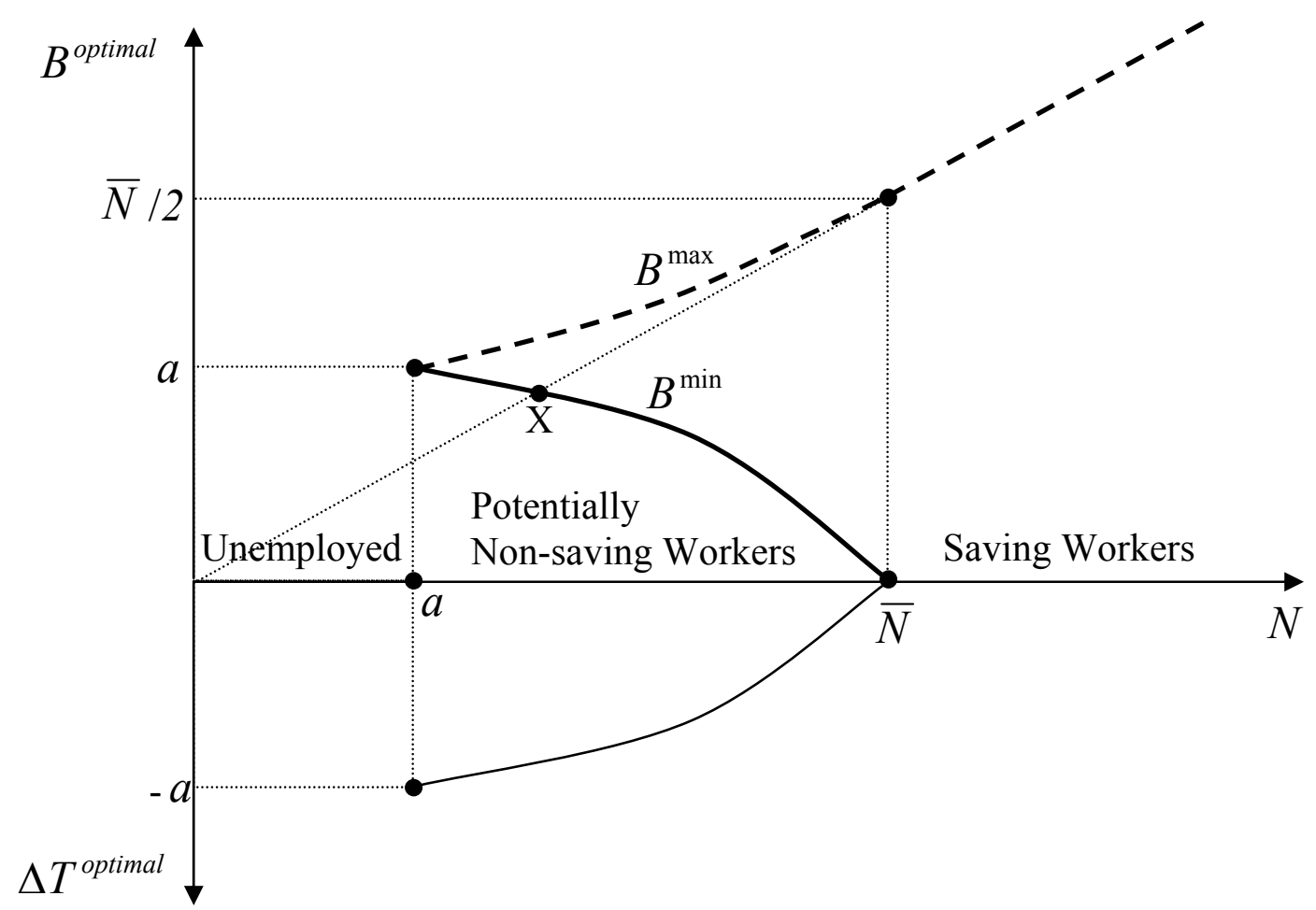

Figure 2: $B^{\min }$ decreases whereas $B^{\max }$ increases with pre-reform after tax income $N$. The required tax break as part of the reform mirrors $B^{\mathrm{min}}$. 
The minimum efficient pension system $B^{\text {min }}$ is justified entirely on the grounds of Hayek's obvious corollary. We therefore call it the Hayek pension. It requires compulsory savings only for the range of $N$ where workers are non-saving. Within this range, as the after tax income decreases and approaches the minimum income from above, it becomes progressively difficult to prevent the agents from free riding on the minimum income in old age. Hence, the required compulsory savings increase as net income decreases. This is in striking contrast to most pension existing pension systems whose benefits typically increase with income. As can been seen in Figure 2, the required tax break to make work sufficiently attractive in the face of high compulsory savings mirrors that shape, since according to (7) $\Delta B+\Delta T=0$ holds.

It is important to note that the Hayek pension we have derived is neither a Beveridge pension with flat benefits nor a Bismarck pension with contribution related benefits. We will now proceed to compare these different pension systems with one another.

\section{Beveridge, Bismarck, and Hayek}

Most countries either have a Beveridge pension with tax financed flat benefits or Bismarck pensions with contributions related benefits or some combination of the two. We discuss the performance of Beveridge and Bismarck pensions in controlling the savings moral hazard compared to the Hayek pension.

First, we ask whether a Bismarck pension system with linear contribution schedule and consequently benefits proportional to (pre-reform after tax) income can efficiently eliminate the savings moral hazard ${ }^{6}$. This turns out that this is not the case. Even a contribution rate of $1 / 2$ of after tax income, the highest linear compulsory savings that would generate a pensions below or at $B^{\max }$ in our model, fails to provide sufficient benefit levels for low incomes. As illustrated in Figure 2, to the left of point $\mathrm{X}$ even this most generous linear compulsory savings schedule would still generate benefits below $B^{\mathrm{min}}$, the minimum required for efficiency. Hence, any linear Bismarck pension system would need to be supplemented by a Hayek pension to assure efficiency. In the German pension debate sometimes the argument is

\footnotetext{
${ }^{6}$ A discussion of the advantages of a funded versus an unfunded Bismarckian pension system is beyond the scope of this paper. For a useful summary of this issue see Sinn (2000), illustrating how a pay-as-you-go pension system can be regarded as a combination of a funded system and an implicit tax used to service an implicit government debt. In doing so, it becomes possible to immediately apply the results of this paper to pay-as-yougo systems.
} 
made that the benefit levels of the Bismarck pension even in the face of our severe demographic crisis mustn't be reduced on the grounds that this would exacerbate the savings moral hazard. Our findings suggest that a Hayek pension needs to be introduced to efficiently deal with the savings moral hazard anyway and that then the issue of reducing benefit levels of the Bismarck pension to deal with the demographic crisis can be addressed quite independently.

Second, we examine whether the introduction of a tax financed flat benefit Beveridge pension would also be Pareto-improving. By inspecting Figure 2 it is clear that that one (and only one) efficient flat benefit level exists that lies wholly between $B^{\min }$ and $B^{\max }$, namely the level of the means tested minimum income for old age $a$. However, while a flat benefit level of $a$ could in itself be just as efficient as the Hayek pension, the tax financing of these flat benefits would induce additional and unnecessary income tax distortions. Partly, these distortions would be caused by additional redistribution between income groups, redistribution which is generally better administered through the tax system instead of the pension system. But more importantly, there would be significant distortions caused by effectively a pooling of savings within each income group. Therefore, if flat benefits for reasons outside the scope of this paper are desired, it would be generally more efficient to finance them Bismarckian style through benefit linked contributions that are capped at the desired benefit level rather than through taxes.

Summing up, we find that the Hayek pension deals with the savings moral hazard more effectively than either the Bismarck or the Beveridge pension. To deal with problems beyond the savings moral hazard discussed in this paper, such as not fully efficient private annuity markets (e.g. Mitchell et al. 1999) or the distrust of citizens in their ability to plan ahead for themselves as alluded to in footnote 2 , it is likely to be desirable to supplement the Hayek pension with a Bismarck pension to reach the desired benefit levels. The tax financed flat benefit Beveridge pension, however, is not likely to be part of an efficient arrangement. 


\section{References}

Cremer, H. and P. Pestieau (1998). "Social Insurance, Majority Voting and Labor Mobility." Journal of Public Economics 68, 397-420.

Diamond, P. (1977). “A Framework A Framework for Social Security Analysis”, Journal of Public Economics 8, 275-298.

Feldstein, M. (1985). “The Optimal Level of Social Security Benefits.” Quarterly Journal of Economics 10(2), 303-320.

Feldstein, M. (1987). “Should Social Security Benefits Be Means Tested?” Journal of Political Economy 95(3), 468-484.

Fenge, R. and J. von Weizsäcker (2002), "Compulsory Savings: Efficiency and Redistribution. On the Interaction of Means Tested Basic Income and Public Pensions", International Tax and Public Finance 8(4), 633-648.

Friedman, M. and W. Cohen (1972), Social Security: Universal or Selective? American Enterprise Institute, Washington DC

Hayek, F.A. von (1960), The Constitution of Liberty, Chicago: University of Chicago Press.

Hubbard, R. G., J. Skinner and S. P. Zeldes. (1995). "Precautionary Saving and Social Insurance.” Journal of Political Economy 103, 360-399.

Homburg, S. (2000), "Compulsory savings in the welfare state", Journal of Public Economics $77,233-239$.

Laibson, D. (1997). “Golden Eggs and Hyperbolic Discounting.” Quarterly Journal of Economics 112, 443-477.

Lindbeck, A. and J. W. Weibull. (1988). "Altruism and Time Consistency: The Economics of Fait Accompli.” Journal of Political Economy 96, 1165-1182. 
Mirrlees, J.A. (1971), "An exploration in the theory of optimum income taxation", Review of Economic Studies 38, 175-208.

Mitchell, O.S, J.M. Poterba, M.J. Warshawsky, and J.R. Brown (1999), "New Evidence on the Money's Worth of Individual Annuities”, American Economic Review, 89(5),1299-1318.

Mulligan, C. B. and X. Sala-i-Martin. (1999), "Social Security in Theory and Practice (II): Efficiency Theories, Narrative Theories, and Implications for Reform.” NBER Working Paper W7119.

Sinn, H.-W. (2000), "Why a Funded Pension is Useful and Why it is not Useful”, International Tax and Public Finance 7, 389-410. 


\section{Appendix}

For ease of exposition, some restrictive assumptions were used to derive the proposition in the main part of the paper. In the following, an indication is given of how the result can be generalized. One replaces the consumption utility $u\left(c_{1}\right)+u\left(c_{2}\right)$ in (1) by the more general function utility function $u\left(c_{1}, c_{2}\right)$ with all the usual characteristics. We allow for a positive interest rate by expressing all second period amounts in first period present value. As a result, (1) is replaced by

$$
U\left(c_{1}, c_{2}, 1-l\right)=u\left(c_{1}, c_{2}\right)+v(1-l)
$$

Furthermore, the means tested minimum income levels are changed to $a_{1}$ in the first and $a_{2}$ in the second period such that the minimum income in those periods is the optimum consumption given total resources $a_{1}+a_{2}$, implying the first order condition

$$
\frac{\partial u\left(a_{1}, a_{2}\right)}{\partial c_{1}}=\frac{\partial u\left(a_{1}, a_{2}\right)}{\partial c_{2}}
$$

Furthermore, the cross derivative for first and second period consumption is assumed to be nonnegative $\partial^{2} u / \partial c_{1} \partial c_{2} \geq 0$ for all net incomes greater than $a_{1}+a_{2}$ so that first and second period consumption are normal and increase monotonically with net income. ${ }^{7}$

From these assumption it follows that for the consumption pattern of any non-saving worker $\left(c_{1}, c_{2}\right)=\left(w l^{*}-T\left(w l^{*}\right)-B\left(w l^{*}\right), a_{2}\right)$ there exists a minimum resource consumption pattern $\left(x_{1}, x_{2}\right)$ with the following properties:

$$
\begin{aligned}
& u\left(x_{1}, x_{2}\right)=u\left(w l^{*}-T\left(w l^{*}\right)-B\left(w l^{*}\right), a_{2}\right) \\
& x_{1}+x_{2}<w l^{*}-T\left(w l^{*}\right)-B\left(w l^{*}\right)+a_{2} \\
& x_{1}>a_{1}, x_{2}>a_{2}
\end{aligned}
$$

\footnotetext{
${ }^{7}$ As income increases from zero it is plausible that second period consumption would remain zero over some initial income range since death from deprivation before the second period would be certain. Our assumption allows for this. The cardinal utility property of a non-negative cross derivative is only required to show that the Hayek pension decreases monotonically with after tax income. The proposition in the main text holds without any restrictions on the cross derivative.
} 
These properties in (20) assure that a resource saving reform $T, B \rightarrow \widetilde{T}, \widetilde{B}$ with a targeted increase in the compulsory savings level and a targeted decrease in the taxes, corresponding to (5), is available for any non-saving worker with income $I$ :

$$
\widetilde{T}(I)=I-x_{1}-x_{2}, \widetilde{B}(I)=x_{1}+x_{2}-I+T(I)+B(I)
$$

The remainder of the proof for the proposition carries through in close analogy to the proof presented above.

For this generalized utility function $B^{\min }$ and $B^{\max }$ also can shown to have the general shape depicted in Figure 2, allowing the same conclusions given in the discussion of Figure 2. To illustrate this, we give the key proof that for $N$ between $a$ and $\bar{N}$ the Hayek pension is decreasing $d B^{\min } / d N<0$.

From (21) it is clear that $B^{\min }=x_{1}(N)+x_{2}(N)-N$. We want to show that

$$
\frac{d B^{\min }}{d N}=\frac{d\left(x_{1}(N)+x_{2}(N)\right)}{d N}-1<0 \Leftrightarrow \frac{d\left(x_{1}(N)+x_{2}(N)\right)}{d N}<1
$$

Equivalently, it suffices to show that the marginal utility of income in the unconstrained case is higher than in the constrained case

(23) $\quad \frac{d u\left(x_{1}(N), x_{2}(N)\right)}{d\left(x_{1}+x_{2}\right)}>\frac{d u\left(N, a_{2}\right)}{d\left(N+a_{2}\right)}=\frac{d u\left(N, a_{2}\right)}{d N}$

But using the Lagrange multipliers, (23) can be equivalently written as

$$
\frac{\partial u\left(x_{1}(N), x_{2}(N)\right)}{\partial x_{1}}>\frac{\partial u\left(N, a_{2}\right)}{\partial N}
$$

But as $\partial^{2} u / \partial c_{1} \partial c_{2} \geq 0$ and $x_{1}(N)<N, x_{2}(N)>a_{2}$ the inequality (24) indeed always holds. 


\section{CESifo Working Paper Series}

(for full list see www.cesifo.de)

998 Daniel Gros, Who Needs Foreign Banks?, July 2003

999 Wolfram Merzyn and Heinrich W. Ursprung, Voter Support for Privatizing Education: Evidence on Self-Interest and Ideology, July 2003

1000 Jo Thori Lind, Fractionalization and the Size of Government, July 2003

1001 Daniel Friedman and Donald Wittman, Litigation with Symmetric Bargaining and TwoSided Incomplete Information, July 2003

1002 Matthew Clarke and Sardar M. N. Islam, Health Adjusted GDP (HAGDP) Measures of the Relationship Between Economic Growth, Health Outcomes and Social Welfare, July 2003

1003 Volker Grossmann, Contest for Attention in a Quality-Ladder Model of Endogenous Growth, August 2003

1004 Marcel Gérard and Joan Martens Weiner, Cross-Border Loss Offset and Formulary Apportionment: How do they affect multijurisdictional firm investment spending and interjurisdictional tax competition?, August 2003

1005 Burkhard Heer, Nonsuperneutrality of Money in the Sidrauski Model with Heterogeous Agents, August 2003

1006 V. Anton Muscatelli, Piergiovanna Natale, and Patrizio Tirelli, A Simple and Flexible Alternative to the Stability and Growth Pact Deficit Ceilings. Is it at hand?, August 2003

1007 Reto Foellmi and Josef Zweimüller, Inequality and Economic Growth: European Versus U.S. Experiences, August 2003

1008 James S. Costain and Michael Reiter, Business Cycles, Unemployment Insurance, and the Calibration of Matching Models, August 2003

1009 Marco Runkel, Optimal Contest Design when the Designer's Payoff Depends on Competitive Balance, August 2003

1010 Donald O. Parsons, Torben Tranaes and Helene Bie Lilleør, Voluntary Public Unemployment Insurance, August 2003

1011 Rüdiger Pethig and Andreas Wagener, Profit Tax Competition and Formula Apportionment, August 2003

1012 Johan Willner, Privatisation and Public Ownership in Finland, August 2003 
1013 Seppo Kari and Jouko Ylä-Liedenpohja, Taxation and Valuation of International Real Investments, August 2003

1014 James Heckman, Rosa Matzkin and Lars Nesheim, Simulation and Estimation of Hedonic Models, August 2003

1015 Biswa N. Bhattacharyay, Towards a Macro-Prudential Leading Indicators Framework for Monitoring Financial Vulnerability, August 2003

1016 J. Stephen Ferris and Stanley L. Winer, Searching for Keynes: With Application to Canada, 1870-2000, August 2003

1017 Massimo Bordignon, Luca Colombo and Umberto Galmarini, Fiscal Federalism and Endogenous Lobbies' Formation, August 2003

1018 Annette Alstadsæter, The Dual Income Tax and Firms' Income Shifting through the Choice of Organizational Form and Real Capital Investments, August 2003

1019 Peter Fredriksson and Bertil Holmlund, Optimal Unemployment Insurance Design: Time Limits, Monitoring, or Workfare?, August 2003

1020 Kashif S. Mansori, Following in their Footsteps: Comparing Interest Parity Conditions in Central European Economies to the Euro Countries, August 2003

1021 Christoph Borgmann and Matthias Heidler, Demographics and Volatile Social Security Wealth: Political Risks of Benefit Rule Changes in Germany, August 2003

1022 Kjell Erik Lommerud, Bjørn Sandvik and Odd Rune Staume, Good Jobs, Bad Jobs and Redistribution, August 2003

1023 Patrick Karl O'Brien, The Governance of Globalization: The Political Economy of Anglo-American Hegemony, 1793-2003, September 2003

1024 Antonio Ciccone and Giovanni Peri, Skills' Substitutability and Technological Progress: U.S. States 1950-1990, September 2003

1025 Bjørn Sandvik, Optimal Taxation and Normalisations, September 2003

1026 Massimo Bordignon and Gilberto Turati, Bailing Out Expectations and Health Expenditure in Italy, September 2003

1027 José A. Herce, Namkee Ahn, Ricard Génova, and Joaquín Pereira, Bio-Demographic and Health Aspects of Ageing in the EU, September 2003

1028 John Komlos and Marieluise Baur, From the Tallest to (One of) the Fattest: The Enigmatic Fate of the American Population in the $20^{\text {th }}$ Century, September 2003

1029 Stefan Napel and Mika Widgrén, Bargaining and Distribution of Power in the EU's Conciliation Committee, September 2003 
1030 Kai Li and Dale J. Poirier, Relationship Between Maternal Behavior During Pregnancy, Birth Outcome, and Early Childhood Development: An Exploratory Study, September 2003

1031 Ivar Ekeland, James J. Heckman, and Lars Nesheim, Identifcation and Estimation of Hedonic Models, September 2003

1032 Kjetil Bjorvatn and Alexander W. Cappelen, Decentralization and the Fate of Minorities, September 2003

1033 Lars-Erik Borge and Jørn Rattsø, The Relationships Between Costs and User Charges: The Case of a Norwegian Utility Service, September 2003

1034 Maureen Were and Nancy N. Nafula, An Assessment of the Impact of HIV/AIDS on Economic Growth: The Case of Kenya, September 2003

1035 A. Lans Bovenberg, Tax Policy and Labor Market Performance, September 2003

1036 Peter Birch Sørensen, Neutral Taxation of Shareholder Income: A Norwegian Tax Reform Proposal, September 2003

1037 Roberta Dessi and Sheilagh Ogilvie, Social Capital and Collusion: The Case of Merchant Guilds, September 2003

1038 Alessandra Casarico and Carlo Devillanova, Capital-skill Complementarity and the Redistributive Effects of Social Security Reform, September 2003

1039 Assaf Razin and Efraim Sadka, Privatizing Social Security Under Balanced-Budget Constraints: A Political-Economy Approach, September 2003

1040 Michele Moretto, Paolo M. Panteghini, and Carlo Scarpa, Investment Size and Firm's Value under Profit Sharing Regulation, September 2003

1041 A. Lans Bovenberg and Peter Birch Sørensen, Improving the Equity-Efficiency Tradeoff: Mandatory Savings Accounts for Social Insurance, September 2003

1042 Bas van Aarle, Harry Garretsen, and Florence Huart, Transatlantic Monetary and Fiscal Policy Interaction, September 2003

1043 Jerome L. Stein, Stochastic Optimal Control Modeling of Debt Crises, September 2003

1044 Thomas Stratmann, Tainted Money? Contribution Limits and the Effectiveness of Campaign Spending, September 2003

1045 Marianna Grimaldi and Paul De Grauwe, Bubbling and Crashing Exchange Rates, September 2003

1046 Assar Lindbeck and Dennis J. Snower, The Firm as a Pool of Factor Complementarities, September 2003 
1047 Volker Grossmann, Firm Size and Diversification: Asymmetric Multiproduct Firms under Cournot Competition, September 2003

1048 Dan Anderberg, Insiders, Outsiders, and the Underground Economy, October 2003

1049 Jose Apesteguia, Steffen Huck and Jörg Oechssler, Imitation - Theory and Experimental Evidence, October 2003

1050 G. Abío, G. Mahieu and C. Patxot, On the Optimality of PAYG Pension Systems in an Endogenous Fertility Setting, October 2003

1051 Carlos Fonseca Marinheiro, Output Smoothing in EMU and OECD: Can We Forego Government Contribution? A Risk Sharing Approach, October 2003

1052 Olivier Bargain and Nicolas Moreau, Is the Collective Model of Labor Supply Useful for Tax Policy Analysis? A Simulation Exercise, October 2003

1053 Michael Artis, Is there a European Business Cycle?, October 2003

1054 Martin R. West and Ludger Wößmann, Which School Systems Sort Weaker Students into Smaller Classes? International Evidence, October 2003

1055 Annette Alstadsaeter, Income Tax, Consumption Value of Education, and the Choice of Educational Type, October 2003

1056 Ansgar Belke and Ralph Setzer, Exchange Rate Volatility and Employment Growth: Empirical Evidence from the CEE Economies, October 2003

1057 Carsten Hefeker, Structural Reforms and the Enlargement of Monetary Union, October 2003

1058 Henning Bohn and Charles Stuart, Voting and Nonlinear Taxes in a Stylized Representative Democracy, October 2003

1059 Philippe Choné, David le Blanc and Isabelle Robert-Bobée, Female Labor Supply and Child Care in France, October 2003

1060 V. Anton Muscatelli, Patrizio Tirelli and Carmine Trecroci, Fiscal and Monetary Policy Interactions: Empirical Evidence and Optimal Policy Using a Structural New Keynesian Model, October 2003

1061 Helmuth Cremer and Pierre Pestieau, Wealth Transfer Taxation: A Survey, October 2003

1062 Henning Bohn, Will Social Security and Medicare Remain Viable as the U.S. Population is Aging? An Update, October 2003

1063 James M. Malcomson, Health Service Gatekeepers, October 2003

1064 Jakob von Weizsäcker, The Hayek Pension: An efficient minimum pension to complement the welfare state, October 2003 